\title{
Principal Supervision Effect on Primary School Teacher Performance
}

\author{
Supervisi Kepala Sekolah Pengaruhnya terhadap Kinerja Guru Sekolah Dasar
}

\author{
Januar Barkah \\ Universitas Indraprasta PGRI \\ Jakarta \\ januar.barkah@unindra.ac.id
}

\author{
Fahmi Hidayat \\ Universitas Indraprasta PGRI \\ Jakarta \\ hidayatlisa@gmail.com
}

\author{
Nurbaity \\ Universitas Indraprasta PGRI \\ Jakarta \\ nurbaity_muthalib@yahoo.com
}

\begin{abstract}
The aims of this study were to determine the effect of principal's supervision on teacher performance. This type of research is a quantitative descriptive research. The population in this study were 43 people from the Integrated Islamic Elementary School, South Jakarta. Samples were taken as much as $30 \%$ of the total population, the number of samples in this study amounted to 43 respondents. The instrument used is a questionnaire. This study concludes that: There is an effect of supervision on teacher performance. Based on the tcount value for Supervision (X) of 6,937 while the ttable value for $n=43$ is 2,048. So 6,937 > 2,048 or rcount > ttable, because the hypothesis is formulated, if the value of tcount > ttable, then $\mathrm{HO}$ is rejected and $\mathrm{Ha}$ is accepted. Meanwhile, based on the correlations table, $R$ of 0,735 was obtained using the formula $K D=R 2 \times 100 \%$, the result was $54,02 \%$.
\end{abstract}

Keywords: supervision, performance

Abstrak

Penelitian ini bertujuan untuk mengetahui pengaruh supervisi kepala sekolah terhadap kinerja guru. Jenis penelitian ini adalah penelitian deskriptif kuantitatif. Populasi dalam penelitian ini adalah 43 orang dari SD Islam Terpadu Jakarta Selatan. Sampel yang diambil sebanyak $30 \%$ dari total populasi, jumlah sampel dalam penelitian ini berjumlah 43 responden. Instrumen yang digunakan adalah angket. Penelitian ini menyimpulkan bahwa: Ada pengaruh supervisi terhadap kinerja guru. Berdasarkan nilai thitung untuk Pengawasan (X) sebesar 6,937 sedangkan nilai ttabel untuk $\mathrm{n}=43$ sebesar 2,048. Jadi 6,937>2,048 atau rhitung > ttabel, karena hipotesis yang dirumuskan, jika nilai thitung > ttabel, maka H0 ditolak dan Ha diterima. Sedangkan berdasarkan tabel korelasi diperoleh $\mathrm{R}$ sebesar 0,735 dengan menggunakan rumus KD $=\mathrm{R} 2 \times 100 \%$ diperoleh hasil $54,02 \%$.

Kata kunci: pengawasan, kinerja

\section{PENDAHULUAN}

Guru sebagai komponen yang penting dalam proses pembelajaran harus memiliki empat kompetensi yang sesuai dengan Peraturan Menteri Pendidikan Nasional Nomor 16 Tahun 2007 mengenai kualifikasi dan kompetensi. Empat kompetensi yang harus dimiliki guru tersebut adalah kompetensi pedagogik, kompetensi kepribadian, kompetesni profesional, dan kompetensi sosial. Dari empat kompetensi yang haru dimiliki oleh guru tersebut dapat menjadi gambaran mengenai kinerja guru dalam melaksanakan tugasnya. 
Dalam upaya mewujudkan kinerja yang baik diperlukan proses penilaian kinerja. Penilaian kinerja guru diartikan sebagai penilaian dari tiap butir kegiatan tugas utama guru dalam kerangka kepangkatan dan jabatannya (Permen PAN No.16 Tahun 2009). Penilaian kinerja guru akan sangat membantu dalam upaya mengelola guru dan mengembangkannya dalam kerangaka mencapai tujuan pendidikan di sekolah (Barnawi dan Arifin, 2012: 25).

Menurut Sedarmayanti (2013: 261) mengemukakan, penilaian kinerja adalah sistem formal untuk memeriksa/mengkaji dan mengevaluasi secara berkala kinerja seseorang. Kinerja dapat pula dipandang sebagai perpaduan: hasil kerja (apa yang harus dicapai oleh seseorang) dan kompetensi (bagaimana, seseorang mencapainya). Pengertian beberapa istilah: penilaian adalah uraian sistematik, tentang kekuatan/kelebihan dan kelemahan yang berkaitan dengan pekerjaan seseorang/kelompok. Periode penilaian adalah lamanya waktu untuk mengobservasikan kinerja karyawan, hasil kerja dibuat menjadi laporan formal. Kinerja sebagai suatu proses untuk menciptakan, pemahaman yang sama tentang apa yang harus dicapai, dan pengelolaan karyawan sehingga meningkatkan kemungkinan tercapainya tujuan.

Berdasarkan observasi awal yang dilakukan peneliti di Sekolah Dasar Islam Terpadu Insan Mandiri Jakarta, dapat dilihat bahwa sekolah yang ada tersebut mempunyai potensi yang sangat besar untuk menjadi sebuah lembaga pendidikan yang dapat diakui kredibilitasnya dan tumbuh menjadi salah satu sekolah unggulan. Hal ini dapat terlihat dari peran serta kepala sekolah dalam peningkatan kinerja guru, letak sekolah yang strategis sehingga tercipta lingkungan belajar yang tertib dan nyaman, pemantauan terhadap peserta didik oleh guru yang berkelanjutan, peran serta dukungan orang tua murid dan masyarakat yang optimal. Salah satu cara yang dapat dilakukan agar hal tersebut dapat tercapai yaitu apabila sekolah tersebut mempunyai seorang pemimpin yang mampu membawa perubahan terhadap kinerja guru.

Kinerja guru yang baik merupakan harapan semua pihak, akan tetapi pada kenyataannya proses pembelajaran oleh guru Sekolah Dasar Islam Terpadu Insan Mandiri Jakarta belum maksimal sesuai yang diharapkan. Hal ini mengacu pada hasil penjajagan yang telah dilakukan, di mana ditemukan adanya fenomena antara lain: dalam perencanaan pembelajaran, dalam pelaksanaan pembelajaran dan dalam penilaian atau evaluasi pembelajaran. Dalam perencanaan pembelajaran, yaitu pembuatan administrasi guru (Rencana Program Pembelajaran/RPP, Program Tahunan, Progam Semester, Silabus, Nilai Kriteria Ketuntasan Minimal/KKM, dan Daftar Nilai), guru hanya menjiplak atau copy paste dari tahun-tahun sebelumnya atau dari orang lain. Guru membuat administrasi bukan sebagai acuan untuk melaksanakan pembelajaran di kelas, sehingga pelaksanaan pembelajaran di kelas relatif tidak terencana, akibatnya hasil belajar yang dicapai peserta didik belum menggembirakan.

Rendahnya kinerja guru bisa dilihat dari adanya gejala-gejala: seperti guru sering membolos/mangkir mengajar, guru yang masuk ke kelas tidak tepat waktu/terlambat. Guru yang mengajar tidak mempunyai persiapan mengajar atau persiapan mengajarnya kurang lengkap. Guru mengajar hanya sebuah rutinitas belaka tanpa adanya inovasi pengembangan lebih lanjut. Di satu sisi, kepala sekolah berperan sebagai pemimpin (Leader) yang memiliki visi ke masa depan yang jelas dan dapat diwujudkan serta mampu mendorong proses transparansi di sekolah. Di sisi lain, kepala sekolah berperan sebagai manajer, yang memiliki strategistrategi yang efektif dan efisien untuk mengimplementasikan berbagai kebijakan dan keputusan yang telah ditetapkan.

Kepala sekolah dasar memegang peranan yang sangat penting di dalam meningkatkan kegiatan pembelajaran. Keseimbangan kinerja guru bahwa setiap individu memperoleh kesamaan digunakan di dalam pendidikan sebagai dasar untuk kesempatan pendidikan dalam pengaruh supervisi kepala sekolah terhadap kinerja guru di Sekolah Dasar Islam Terpadu Insan Mandiri, berdasarkan tujuan dari manajemen sekolah itu untuk memajukan dan membantu proses pembelajaran, semua guru di sekolah dasar memiliki peran langsung di mana mereka bekerja. 
Kinerja guru juga dipengaruhi oleh supervisi kepala sekolah. Sergiovani seperti yang dikutip oleh Mulyasa (2007: 111) menyatakan bahwa supervisi merupakan suatu proses yang dirancang secara khusus untuk membantu para guru dan supervisor dalam mempelajari beragam macam tugasnya sehari-hari disekolah, agar dapat menggunakan pengetahuan dan kemampuannya untuk memberikan layanan yang lebih baik pada orang tua peserta didik dan sekolah sebagai masyarakat belajar yang efektif. Ada kecenderungan yang kuat bahwa untuk meningkatkan kualitas layanan dalam kualifikasi profesionalisme guru yang perlu dibina dan ditata kembali adalah kemampuannya sehingga pada gilirannya dapat digunakan untuk mengarahkan program guru agar menjadi sosok yang profesional dalam pendidikan.

Hal ini tidak terlepas dari bantuan dan bimbingan dari supervisor. Dalam melaksanakan tugasnya, seorang supervisor berkewajiban membantu guru memberi dukungan yang dapat melaksanakan tugas dengan baik sebagai pendidik maupun pengajar. Supervisi yang dilakukan oleh kepala sekolah yaitu untuk meningkatkan kompetensi para guru dalam kegiatan belajar mengajar, sehingga diharapkan dapat memenuhi misi pengajaran yang diembannya atau misi pendidikan nasional dalam lingkup yang lebih luas. Sebagaimana yang kita ketahui bersama bahwa masalah profesi guru dalam mengemban kegiatan belajar mengajar akan selalu dan terus berlanjut dan bantuan supervisi dari kepala sekolah sangatlah penting dalam mengembangkan profesionalisme guru dalam melaksanakan tugasnya secara maksimal. Kepala sekolah menghendaki dukungan kinerja guru yang selalu ada peningkatan yang konsisten dalam melaksanakan pembelajaran disekolah.

\section{METODE}

Jenis penelitian yang digunakan dalam penelitian ini adalah penelitian kuantitatif. Metode penelitian kuantitatif, sebagaimana dikemukakan oleh Sugiyono (2011: 8) yaitu: "Metode penelitian yang berlandaskan pada filsafat positivisme, digunakan untuk meneliti pada populasi atau sampel tertentu, pengumpulan data menggunakan instrumen penelitian, analisis data bersifat kuantitatif/statistik, dengan tujuan untuk menguji hipotesis yang telah ditetapkan". Instrumen pengumpulan data dalam penelitian ini adalah dengan penyebaran kuesioner berupa sejumlah pertanyaan berstruktur yang harus dijawab oleh responden.

\section{HASIL DAN PEMBAHASAN}

\section{Hasil}

\section{Descriptive Statistics}

\begin{tabular}{|l|c|c|c|}
\hline & Mean & Std. Deviation & N \\
\hline Kinerja Guru (Y) & 44,8605 & 4,02718 & 43 \\
Supervisi Kepala Sekolah (X) & 42,2326 & 3,84111 & 43 \\
\hline
\end{tabular}

Berdasarkan tabel tersebut di atas, untuk mengetahui nilai mean (rata-rata) persepsi responden terhadap indikator-indikator variabel Supervisi $(\mathrm{X})$ memiliki nilai mean sebesar 42,2326, Standard Deviasi 3,84111 dan variabel Kinerja Guru (Y) memiliki nilai mean sebesar 44,8605, Standar Deviasi 4,02718. 


\section{Correlations}

\begin{tabular}{|c|c|c|c|}
\hline & & Kinerja Guru (Y) & $\begin{array}{c}\text { Supervisi Kepala } \\
\text { Sekolah (X) }\end{array}$ \\
\hline \multirow[t]{2}{*}{ Pearson Correlation } & Kinerja Guru (Y) & 1,000 & ,735 \\
\hline & Supervisi Kepala Sekolah (X) & ,735 & 1,000 \\
\hline \multirow[t]{2}{*}{ Sig. (1-tailed) } & Kinerja Guru (Y) & & ,000 \\
\hline & Supervisi Kepala Sekolah (X) & ,000 & \\
\hline \multirow[t]{2}{*}{$\mathrm{N}$} & Kinerja Guru (Y) & 43 & 43 \\
\hline & Supervisi Kepala Sekolah (X) & 43 & 43 \\
\hline
\end{tabular}

Coefficients $^{\mathbf{a}}$

\begin{tabular}{|c|c|c|c|c|c|}
\hline \multirow[b]{2}{*}{ Model } & \multicolumn{2}{|c|}{$\begin{array}{c}\text { Unstandardized } \\
\text { Coefficients }\end{array}$} & \multirow{2}{*}{\begin{tabular}{|c|}
$\begin{array}{l}\text { Standardized } \\
\text { Coefficients }\end{array}$ \\
Beta \\
\end{tabular}} & \multirow[t]{2}{*}{$\mathrm{t}$} & \multirow[t]{2}{*}{ Sig. } \\
\hline & B & Std. Error & & & \\
\hline (Constant) & 12,325 & 4,709 & & 2,617 & ,012 \\
\hline $\begin{array}{l}\text { Supervisi Kepala } \\
\text { Sekolah (X) }\end{array}$ & ,770 & ,111 & ,735 & 6,937 & ,000 \\
\hline
\end{tabular}

Untuk menentukan nilai persamaan regresi linear bergandanya sebagai berikut: $\mathrm{Y}=$ $12,325+0,770 \mathrm{X}$

Dapat dijelaskan sebagai berikut:

1. Nilai konstanta intersep sebesar 12,325 menyatakan bahwa jika variabel Supervisi (X) meningkat I satuan, maka variabel Kinerja Guru (Y) akan meningkat sebesar 12,325.

2. Nilai koefisien regresi variabel Supervisi Kepala Sekolah (X) terhadap variabel Kinerja Guru (Y) adalah sebesar 0,770. Hal ini berarti jika variabel Supervisi Kepala Sekolah (X) meningkat 1 satuan maka variabel Kinerja Guru (Y) akan meningkat sebesar 0,770.

\section{Pembahasan}

Berdasarkan tabel analisis regresi linier berganda di atas, maka nilai thitung untuk Supervisi (X) sebesar 6,937 sedangkan nilai ttabel untuk $n=43$ adalah sebesar 2,048. Jadi 6,937 $>$ 2,048 atau rhitung > ttabel, karena hipotesis tersebut dirumuskan, jika nilai thitung $>$ ttabel, maka $\mathrm{H}_{0}$ ditolak dan $\mathrm{H}_{\mathrm{a}}$ diterima. Dengan terbukti bahwa $\mathrm{t}_{\text {hitung }}>\mathrm{t}_{\text {tabel }}$ dapat dinyatakan bahwa Supervisi memang memiliki pengaruh positif terhadap kinerja guru Sekolah Dasar. Sedangkan berdasarkan tabel correlations diperoleh $\mathrm{R}$ sebesar 0,735 dengan menggunakan rumus $\mathrm{KD}=\mathrm{R}^{2}$ x 100\%, diperoleh hasil 54,02\%.

Keberhasilan pendidikan di sekolah ditentukan oleh berhasil tidaknya kepala sekolah dalam mengelola tenaga pendidik yang ada di sekolah. Tenaga pendidik yang mempunyai kinerja yang baik akan mampu menumbuhkan semangat dan motivasi belajar peserta didik yang lebih baik, yang pada akhirnya akan mampu meningkatkan kualitas pembelajaran. Kepala sekolah mempunyai peranan yang sangat berpengaruh di lingkungan sekolah yang menjadi tanggungjawabnya. Kinerja guru merupakan kemampuan guru dalam melaksanakan tugas sesuai dengan motivasinya, sehingga terjadi perubahan pada diri peserta didik baik pada aspek kognitif, afektif, dan psikomotorik sebagai hasil dari upaya guru dalam mendidik peserta didik hal itu dapat terrwujud salah satunya dengan supervisi kepala sekolah. Supervisi akan terwujud apabila seorang pemimpin atau kepala sekolah memberikan petunjuk-petunjuk kepada bawahannya, 
mengadakan pengawasan serta motivasi sehingga dapat menimbulkan kepuasan bagi guru sehingga diharapkan hal tersebut dapat meningkatkan kinerja guru itu sendiri.

Pelaksanaan supervisi oleh kepala sekolah ialah supervisi akademik. Menurut Direktorat Tenaga Kependidikan (2010:6) Kompetensi supervisi akademik intinya adalah membina guru dalam meningkatkan mutu proses pembelajaran. Sasaran supervisi akademik adalah guru dalam melaksanakan proses pembelajaran, yang terdiri dari materi pokok dalam proses pembelajaran, penyusunan silabus dan RPP, pemilihan strategi atau metode pembelajaran, penggunaan media dan teknologi informasi dalam pembelajaran, menilai proses serta hasil pembelajaran.

\section{PENUTUP}

Terdapat pengaruh supervisi terhadap kinerja guru di Sekolah Dasar Islam Terpadu Insan Mandiri Jakarta. Berdasarkan nilai thitung untuk Supervisi (X) sebesar 6,937 sedangkan nilai ttabel untuk $n=43$ adalah sebesar 2,048. Jadi 6,937 $>2,048$ atau $r_{\text {hitung }}>t_{\text {tabel, }}$, karena hipotesis tersebut dirumuskan, jika nilai $\mathrm{t}_{\text {hitung }}>\mathrm{t}_{\text {tabel }}$, maka $\mathrm{H}_{0}$ ditolak dan $\mathrm{H}_{\mathrm{a}}$ diterima. Dengan terbukti bahwa $t_{\text {hitung }}>t_{\text {tabel }}$ dapat dinyatakan bahwa Supervisi memang memiliki pengaruh positif terhadap kinerja guru Sekolah Dasar. Sedangkan berdasarkan tabel correlations diperoleh R sebesar 0,735 dengan menggunakan rumus $\mathrm{KD}=\mathrm{R}^{2} \mathrm{x} 100 \%$, diperoleh hasil 54,02\%.

\section{DAFTAR PUSTAKA}

Arifin, M. \& Barnawi. (2012). Kinerja Guru Profesional, Instrumen KGSSH Pembinaan, Peningkatan \& Penilaian. Yogyakarta: Ar-Ruzz Media.

Direktorat Tenaga Kependidikan. (2010). Buku Kerja Pengawas Sekolah. Jakarta: Kementerian Pendidikan Nasional.

Mulyasa, E. (2007). Standar Kompetensi dan Sertifikasi Guru. Bandung: PT. Remaja Rosdakarya.

Sedarmayanti. (2013). Manajemen Sumber Daya Manusia. Bandung: Refika.

Sugiyono. (2011). Metode Penelitian Kuantitatif, Kualitatif dan R\&D. Bandung: Afabeta. 